\title{
Sustainable site clean-up from megaprojects: lessons from London 2012
}

1 Deyi Hou PhD, PE, LEED AP

Project Manager, Parsons Corporation, Walnut Creek, CA, USA

2 Abir Al-Tabbaa PhD, CEng, FICE

Professor, University of Cambridge, Cambridge, UK
3 Jan Hellings MSc, PhD, DIC, MBA, CEng, FICE Former Project Sponsor at Olympic Delivery Authority
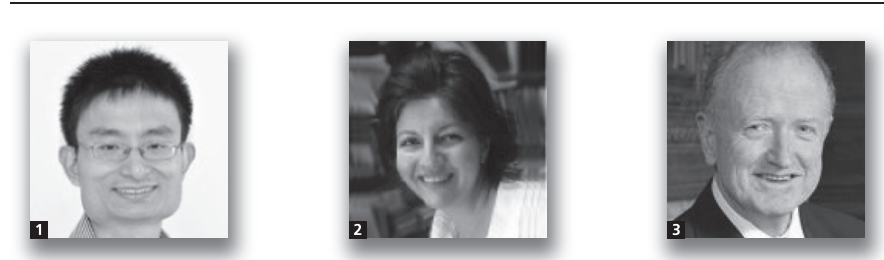

The London 2012 Olympic and Paralympic Games are considered to have been a great success for the UK. In building the Olympic Park, another great achievement was the clean-up and reuse of a large area of contaminated land. A remediation project of this size would typically take 5 to 15 years to complete, but the project team completed the remediation work in less than 3 years. This study provides an in-depth examination of the remediation practices at the site, mainly from the perspective of sustainable construction. Data were collected from multiple sources, including project files, publications by various government agencies and non-governmental organisations, as well as qualitative interviews with project team members. The paper first presents a review of brownfield redevelopment and sustainable remediation literature. Sustainability initiatives and achievements in the Olympic Park site remediation project are summarised and discussed. These mainly included suitable remediation strategies, recycling and reuse of contaminated soil by using soil washing and innovative in situ remediation of contaminated groundwater through bioremediation. The paper identifies a number of challenges and lessons learned regarding brownfield remediation in megaprojects, which warrant further technological development and appropriate policy actions to address.

\section{Introduction}

Megaprojects refer to large-scale development projects that involve a costly scheme for development (Fainstein, 2008), requiring the creation of new structures, equipment and prepared development sites (Altshuler and Luberoff, 2003). Critiques of megaprojects in the 1960s-1980s, often based on their negative environmental and social consequences, led to a decline in megaprojects in the 1980s and 1990s (Orueta and Fainstein, 2008). However, the transition into the twenty-first century saw a revival of megaprojects (Fainstein, 2008; Orueta and Fainstein, 2008), many of which were related to highprofile events such as the Olympic Games in Sydney (2000), Beijing (2008) and London (2012).

Sustainability has been increasingly called on in these new megaprojects. The 2008 Beijing Olympics, for instance, was claimed to be a 'green, high-tech and people's Olympics', with
US $\$ 12 \cdot 2$ billion spent on environmental improvement projects (Beyer, 2006). The 2012 London Olympics carried the theme of 'towards a one planet Olympics', which aimed to advance the UK towards 'one planet living' (ODA, 2007a). One of the main environmental gains from megaprojects is the development of previously contaminated and deprived areas. Quite often, megaprojects are located on landfill or abandoned industrial sites (Fainstein, 2008). The reuse of such abandoned sites usually requires the remediation of some contaminated areas, including contaminated soil, groundwater and sediment. For instance, the 2000 Sydney Olympic Park involved the remediation of a former industrial area that was selected for urban renewal (Short, 1993), and the 2008 London Olympic Park involved the remediation of contaminated land and rivers (ODA, 2007b).

The remediation of such brownfields as part of megaprojects can achieve many environmental gains; it can, however, also 
Engineering Sustainability

Volume 168 Issue ES2
Sustainable site clean-up from

megaprojects: lessons from

London 2012

Hou, Al-Tabbaa and Hellings draw criticism. For instance, the remediation work in the case of Sydney 2000 was criticised to be 'a cheap, dirty, quick, and convenient option' rather than best practice (Lenskyj, 1998). Therefore, it is important to identify sustainable means of remediation in such megaprojects. It is worth pointing out that such sustainable means may not necessarily equal green and sustainable remediation practices that are observed in the larger contaminated land remediation community, because remediation in megaprojects has its own challenges in meeting delivery deadlines and budget constraints. The present study provides an in-depth examination of remediation practice at the London Olympic Park, with the aim of providing lessons learned to policy-makers, development decision-makers, engineering designers and construction contractors.

\section{Materials and methodology}

The present study is a retrospective review conducted postOlympics; therefore the authors were not able to conduct a longitudinal study. Instead, the aim was to reconstruct events using several sources of information. The primary source of information was project documents, including site investigation results, global and site-specific remediation strategies, remediation design statements and remediation validation reports. This source of information was used to identify the history and pre-development status of the London Olympic Park site, the decision-making process, sustainability strategies and issues, design processes and remediation facts. Over 10000 project documents were downloaded from planning authorities' websites and additional documents were obtained directly from the Olympic Delivery Authority (ODA) using requests under the Freedom of Information Act. The second source of information included over 100 reports published by related government agencies and non-governmental organisations (NGOs), as well as information obtained from newspapers and journals. This source of information was used to confirm findings from the first source. In addition, this source of information was used to identify challenges and lessons learned, as well as facts related to social and economic sustainability issues. The third source of information was qualitative interviews with two anonymous decision-makers who worked on remediation at the Olympic Park site. The interviewees were assured anonymity and confidentiality and that no business-sensitive information would be released. This source of information was used to identify challenges and lessons learned during the course of the remediation process.

This study uses a single, exploratory case study to investigate how sustainability may be incorporated into brownfield redevelopment. The setting for this specific case, however, can be considered exemplary for a range of situations due to the fact that the Olympic Park site involved many different types of contamination and levels of contamination severity. Some unique features of the project (e.g. large scale, high profile, unmovable delivery dates) make it a perfect case for studying the effect of these factors. The authors argue that these considerations justify the use of a single case and its specific suggestions to deal with the broader sustainability issue.

\section{Brownfield redevelopment and sustainable remediation}

Many megaprojects are conducted on previously developed sites where land contamination exists due to historical human activities, and remediation thus becomes necessary in order to reuse the contaminated land. For example, the site of the 2000 Sydney Olympics Park was historically largely used for uncontrolled landfilling together with former industrial uses. In order to develop the brownfield, contaminated soils were concentrated and contained within encapsulated areas, peripheral to the main development areas, and the capped areas were used as recreational open space and, in some cases, temporary overflow car parks (Short, 1993). The reuse of such brownfield sites avoids development on greenfield and reduces urban sprawl. On the other hand, it also poses a challenge in cleaning up the contaminated soil, groundwater and sediment.

Sustainable remediation is a relatively new concept in the remediation field, which has drawn much attention in the last decade or so (Hou and Al-Tabbaa, 2014; Hou et al., 2014a). In a framework developed by Surf-UK (Sustainable Remediation Forum in the UK, a sustainable remediation network established in the UK in 2007) and Cl:aire (Contaminated Land: Applications in Real Environments, a UK not-for-profit organisation founded in 1999), sustainable remediation is defined as (Surf-UK, 2010)

remediation that eliminates and/or controls uncontrollable risks in a safe and timely manner, and which maximises the overall environmental, social, and economic benefits of the remediation work.

The sustainable remediation concept emerged approximately a decade ago. In the early 2000s, European policy-makers and industrial associations started to advocate a risk-based approach in contaminated land management (Clarinet, 2002a, 2002b; Nicole, 2002). In the risk-based land management framework developed by Clarinet (a network of mainly contaminated land policy-makers and advisers from national ministries and environmental agencies in Europe), sustainability is a key objective that includes the evaluation and optimisation of environmental, economic and social factors (Nicole, 2005). In addition to risk management, the sustainable remediation concept in Europe has strong 'development' components and 'cost saving' components, and sustainable remediation is usually considered in the context of sustainable development (Nicole, 2008). There is a variety of criteria in determining whether a remediation alternative is sustainable. As discussed by Al-Tabbaa et al. (2007), such criteria may include 
Engineering Sustainability

Volume 168 Issue ES2
Sustainable site clean-up from

megaprojects: lessons from

London 2012

Hou, Al-Tabbaa and Hellings
- future benefits outweigh the cost of remediation

the environmental impact of implementation of the remediation process is less than the impact of leaving the land untreated

- the environmental impact of bringing about the remediation process is minimal and measurable

a the timescale over which the environmental consequences occur, and hence inter-generational risk, is part of the decision-making process

the decision-making process includes an appropriate level of engagement of all stakeholders.

Increased recognition of secondary adverse effects associated with remediation operations is one of the main driving forces that has helped shift the industry towards sustainable remediation (Ellis and Hadley, 2009). In order to account for secondary adverse effects, life cycle assessment (LCA) has been increasingly used in both research and practice in the environmental remediation field (Hou et al., 2014b; Morais and DelerueMatos, 2010). The goal of LCA is to quantify the full range of environmental effects associated with a product or a service in order to support decision-making.

In a typical LCA, the first step is to determine the goal and scope, including the functional unit that defines the product or service being studied, thus providing a reference point for quantifying inputs and outputs, as well as the system boundary, which identifies what processes are included in the LCA. Following the first step, a life cycle inventory is conducted by creating an inventory of flows from and to nature for the product or service system. Subsequently, a life cycle impact assessment is conducted to evaluate the environmental impact due to the flows from and to nature. In the last step of LCA, the results are summarised and used to select preferred choices and to improve selected processes. A number of academic research studies have been conducted on the environmental impact of environmental remediation using LCA (Hou et al., 2014c; Lemming et al., 2010). The measures used to reduce the life cycle impact of remediation have become the core of the current sustainable remediation movement. For example, in the Glasgow 2014 Commonwealth Games athletes' village remediation project, remediation practitioners calculated the life cycle 'carbon footprint'; this identified the key carbon dioxide contributors and was considered a useful management tool for the ongoing project (Sampson et al., 2013).

\section{London Olympic Park case study}

\subsection{History and pre-development status of the London Olympic Park site}

The 2012 London Olympic Park site is located in east London and is part of the Lower Lea Valley. It is situated approximately $5 \mathrm{~km}$ from central London, extending across the boundaries of the London boroughs of Hackney, Newham, Tower Hamlets and
Waltham Forest (ODA, 2007c). Prior to redevelopment, the area suffered from a fragmented urban structure, deficiencies in the provision of amenities and limited opportunities for the local population. The wards in the Lower Lea Valley were generally within the 10\% most deprived in England, some of them in the 5\% most deprived. These areas had high unemployment (double the average for England), a low proportion of managerial and professional skills, poor health and high crime rates. Land uses were generally low value and poor quality, interspersed with vacant and derelict sites, creating a poor-quality overall environment with the appearance of considerable neglect. The waterways in the area had also deteriorated, having become silted up and overgrown. Moreover, the combined sewer system had insufficient capacity to handle stormwater discharge during peak time; consequently, two overflow points in the area discharge untreated effluent into the Lea River waterway system. Historical usage of the site included oil refineries, chemical works, cold storage facilities, landfills and backfilled reservoirs, car compounds and warehouse/distribution centres. The site is also fragmented by numerous highways, railway lines and waterways, making accessibility within the area difficult. Site investigation identified soil and groundwater contamination by a range of contaminants, including volatile organic compounds, semi-volatile organic compounds, total petroleum hydrocarbon, heavy metals, cyanide, ammonia, etc.

\subsection{Decision-making process for remediation at London Olympic Park}

The overall decision-making for remediation at the site involved several key stakeholders: the local planning authority, the Environmental Agency (EA), planning consultants and design/ construction contractors. The primary regulator was the ODA planning decision team (PDT), a dedicated team of town planners acting as the local planning authority, which was established through the London Olympic Games and Paralympic Games Act 2006. The PDT registered and validated all applications within the ODA planning boundary. The EA acted as a major regulatory consultee, providing guidance on the main licences and consents required and detailing processes to be followed by designers and contractors. The PDT also retained independent consultants to review the work of designers and contractors. Overall, there was a large group of stakeholders involved in the decision-making processes.

The overall process for remediation consisted of the following five steps.

- A site investigation was conducted to facilitate detailed remediation design.

- A global remediation strategy (GRS) was developed to establish site-wide principles and procedures.

- Site-specific remediation strategies were developed to establish site-specific remediation requirements at each specific construction zone. 
Engineering Sustainability

Volume 168 Issue ES2
Sustainable site clean-up from

megaprojects: lessons from

London 2012

Hou, Al-Tabbaa and Hellings
- A remediation method statement was developed to provide details of the options appraisal and implementation plan for the remediation.

- Remediation design was implemented and a remediation validation report was provided to confirm the appropriateness of the remediation work that was conducted.

\subsection{Overall sustainability strategy and issues related to remediation}

The ODA was the public body responsible for ensuring delivery of the new venues and infrastructure for the Games and the subsequent transformation of the facilities into their legacy form. The published ODA sustainable development strategy (ODA, 2007a) included 12 sustainability objectives concerning: carbon dioxide; water; waste; materials; biodiversity and ecology; land, water, noise and air impacts; supporting communities; transport and mobility; access; employment and skills; health and wellbeing; and inclusion. Among these objectives, the following are considered to be especially relevant to the brownfield remediation work.

Carbon dioxide: to minimise the carbon dioxide emissions; the uses of electricity and diesel fuels during remediation were most relevant to this objective.

Water: to optimise opportunities for efficient water use, reuse and recycling; the recycling of wastewater was most relevant.

Waste: to optimise opportunities to design out waste and to maximise the reuse and recycling of materials arising during remediation and construction.

Materials: to identify, source and use environmentally and socially responsible materials; sustainable procurement during remediation was considered relevant.

- Land, water, noise and air impacts: to optimise positive and minimise adverse impacts on land, water, noise and air quality; both remediation design and remediation implementation were relevant to this objective.

- Health and wellbeing: to provide for healthy lifestyle opportunities during the construction of, and in the design of, the Olympic Park and other venues; the overall remediation work had a direct contribution to this objective.

- Inclusion: to involve, communicate and consult effectively with stakeholders and the diverse communities surrounding the Olympic Park and venues; public participation during remediation planning and implementation was relevant to this objective.

\subsection{Suitable-for-use remediation design}

The remediation work at the site started with initial ground investigation work. Based on this initial investigation, a conceptual site model was constructed and site-wide remediation strategies were developed. A GRS was developed to provide a common resource for remediation strategy-related work in each contaminated area, thus minimising duplication of design, regulatory requirements and programme risk (ODA, 2007b). The GRS was developed broadly in accordance with CLR 11: Model procedures for the management of land contamination (Defra and EA, 2004), but the risk assessment was mainly conducted using a risk-based corrective action model. In the global conceptual site model, the human health receptors included spectators, athletes and officials during the Games, as well as residential children and commercial works associated with legacy land uses. Construction workers were not part of the modelled receptors because it was considered that risks to construction workers would be largely mitigated by construction health and safety measures. The receptor of controlled waters was mainly considered to be the waterways within the Olympic Park, and there was not considered to be a site-wide significant pathway to the underlying chalk aquifer. Shallow groundwater was not considered a significant receptor, but was considered a potential contaminant pathway to controlled waters.

Based on the GRS, one site-specific remediation strategy (SSRS) was developed for each of 20 construction zones. The SSRS took into account specific conditions different from those in the GRS model. In both the GRS and SSRS, a series of toxicity parameters (e.g. a target risk level of $1 \times 10^{-5}$ ) was used to derive clean-up criteria for soil and groundwater under different use scenarios. The clean-up criteria vary dramatically depending on the depth of soil and the type of land use in the specific area (ODA, 2007b). Table 1 lists the soil clean-up criteria for benzene as an illustration. The maximum clean-up level for benzene was $27505 \mathrm{mg} / \mathrm{kg}$, for Olympic land use below $1 \mathrm{~m}$ in hard landscaping areas, and the minimum cleanup level for benzene was $0.023 \mathrm{mg} / \mathrm{kg}$, for legacy land use in the top $1 \mathrm{~m}$ in the athletes' village. The clean-up level for this one compound thus ranged six orders of magnitude. The risk-based and clean-up goal can significantly reduce the number of areas needing aggressive remediation. In order to protect human health, a $0.6 \mathrm{~m}$ thick separation layer was established throughout the site to isolate occupants from any residual below-ground contamination. A marker layer was placed at the bottom of the separation layer, consisting of a brightly coloured geotextile fabric. The separation layer materials were mainly imported clean fill, crushed bricks and concrete, and Thanet sand obtained from on-site tunnelling work.

\subsection{Sustainable remediation technologies and operations}

In choosing sustainable treatment technologies, the ODA remediation design statement (ODA, 2007d) included two considerations

a minimisation of energy consumption and carbon footprint of treatment technologies 


\begin{tabular}{|c|c|c|c|c|}
\hline & \multicolumn{2}{|c|}{ Below $1 \mathrm{~m}$} & \multicolumn{2}{|c|}{ Top $1 \mathrm{~m}$} \\
\hline & Olympic land use & Legacy land use & Olympic land use & Legacy land use \\
\hline Soft landscaping: mg/kg & 150 & 43 & 21 & $6 \cdot 1$ \\
\hline Hard landscaping: mg/kg & 27505 & 7934 & 4126 & 1190 \\
\hline Athletes' village: $\mathrm{mg} / \mathrm{kg}$ & N/A & 0.042 & $\mathrm{~N} / \mathrm{A}$ & 0.023 \\
\hline Stadia: $\mathrm{mg} / \mathrm{kg}$ & $3 \cdot 6$ & $1 \cdot 9$ & $2 \cdot 7$ & $1 \cdot 4$ \\
\hline
\end{tabular}

Table 1. Human health soil clean-up levels for benzene (ODA, 2007b)

a minimisation of remediation resulting in long term management requirements for future generations.

These two considerations deal with environmental sustainability and socioeconomic sustainability, respectively. Based on these sustainability considerations, the ODA ranked preselected soil remediation technologies in the following descending order

1. complex sorting

2. bioremediation

3. soil washing

4. soil stabilisation

5. thermal desorption.

Groundwater remediation technologies were also broadly ranked as

1. groundwater treatment

2. in-ground barrier.
The remediation work was conducted by two tier 1 contractors, one covering the northern part and the other the southern part of the site. In addition, a number of specialist contractors, termed tier 2 contractors, were managed by a tier 1 contractor to conduct specialised remediation work. The main remediation activities and sustainable practices/achievements are summarised in Table 2. The biggest direct sustainable achievement was the washing and reuse of $700000 \mathrm{~m}^{3}$ of contaminated soil. As discussed in Section 4.6, this reduced a substantial environmental impact in comparison with traditional landfilling options. During the peak of remediation operations, five soil washing machines were in operation at the site. This large-scale application of soil washing enabled ODA to win a brownfield briefing remediation award and the regeneration and renewal's environmentally sustainable regeneration scheme of the year award in 2009 (CSL, 2010).

\subsection{Life cycle environmental footprint reduction}

As discussed earlier, the use of soil washing is considered to have brought significant sustainability gain. In order to

\begin{tabular}{ll}
\hline Work phase & Scope of work \\
\hline $\begin{array}{l}\text { Site investigation, demolition } \\
\text { and clearance }\end{array}$ & $\begin{array}{l}\approx 3500 \text { Investigation points at } \approx 25 \mathrm{~m} \text { centres } \\
\text { across site; demolition of } \approx 200 \text { buildings, } \\
\text { generating } 454000 \mathrm{t} \text { of arisings }\end{array}$ \\
$\begin{array}{l}\text { Excavation and placement of } \\
\text { separation layer }\end{array}$ & $\begin{array}{l}\approx \text { Million } \mathrm{m}^{3} \text { of soil excavation; } 0.6 \mathrm{~m} \\
\text { thick separation layer across the site }\end{array}$ \\
Contaminated soil treatment & $\begin{array}{l}\text { Treatment of contaminated soil by soil } \\
\text { washing }\left(700000 \mathrm{~m}^{3}\right), \text { complex sorting } \\
\left(82000 \mathrm{~m}^{3}\right), \text { ex situ stabilisation (50 000 } \mathrm{m}^{3} \text { ) }\end{array}$ \\
$\begin{array}{l}\text { Contaminated groundwater } \\
\text { and bioremediation }\left(30000 \mathrm{~m}^{3}\right)\end{array}$ \\
$\begin{array}{l}\text { Treatment of } \approx 200000 \mathrm{~m}^{3} \text { contaminated } \\
\text { groundwater with pump and treat methods, } \\
\text { in situ chemical oxidation } / \text { reduction, in situ } \\
\text { bioremediation and cut-off walls }\end{array}$
\end{tabular}

Sustainable practices and achievements

$98 \%$ Reuse or recycling of arising materials from demolition and clearance

Recycling of demolition waste through the use of crushed bricks and concrete derived from demolition works After soil washing, 80-85\% was reused as sand and gravel, 15-20\% was disposed of as filter cake containing silt, clay and organic matter; bioremediated soil was used as general fill Use of innovative in situ treatment technologies

Table 2. Remediation activities and sustainable practices at the London Olympic Park site (Hellings et al., 2011) 
Engineering Sustainability

Volume 168 Issue ES2
Sustainable site clean-up from

megaprojects: lessons from

London 2012

Hou, Al-Tabbaa and Hellings estimate the life cycle environmental benefit of soil washing, a quantitative method was used to compare the soil washing technology with an alternative method (landfilling). The quantitative method used in this study is the LCA method. The LCA was conducted in accordance with the international standard (ISO, 2006), following four steps

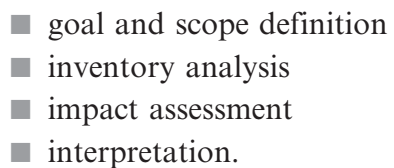

In the LCA, the functional unit was defined as treating $700000 \mathrm{~m}^{3}$ of contaminated soil. The process inventory data were collected according to ISO 14040 on LCA (ISO, 2006). The system boundary was cradle to grave, encompassing the acquisition of raw materials and energy, transportation to and from the site, on-site operation and waste disposal. The reuse of treated soil by soil washing avoided the need to import clean soil, and the avoided environmental burden associated with this was also accounted for. Upstream and downstream material flow and emissions data were collected using existing databases, primarily the Swiss Ecoinvent database (Frischknecht et al., 2007). For impact assessment, the ReCiPe impact assessment method was used (Goedkoop et al., 2013). The ReCiPe model utilises USES-LCA (Van Zelm et al., 2009) to simulate the multi-media fate, exposure and effects. The ReCiPe method has both midpoint and endpoint indicators. The present study used the default ReCiPe endpoint method, hierarchist version. ReCiPe includes three main impact categories - ecosystem, human health and resources. The endpoint method can integrate results for various impact categories to render a single final score, thus allowing for a straightforward interpretation in a management and decision-making oriented setting. The impact assessment results were used to compare the environmental sustainability of soil washing against landfilling.

As shown in Figure 1, the use of soil washing dramatically reduced the life cycle environmental impact. In the ecosystem impact category, soil washing had a negative environmental impact of $-28847 \mathrm{ReCiPe}$ points, suggesting that the avoided emissions due to soil reuse exceeded the emissions from soil washing itself. In comparison, if landfilling was used, the remediation operation would have an environmental impact of 181845 points. In the human health impact category, soil washing reduced the life cycle impact from 725277 points to 92645 points, representing an $87 \%$ reduction. In the resource category, soil washing reduced the life cycle impact from 973319 points to 123423 points, also representing an $87 \%$ reduction.

From the LCA results, it is apparent that soil washing, when compared with the landfilling option, resulted in a lower risk to

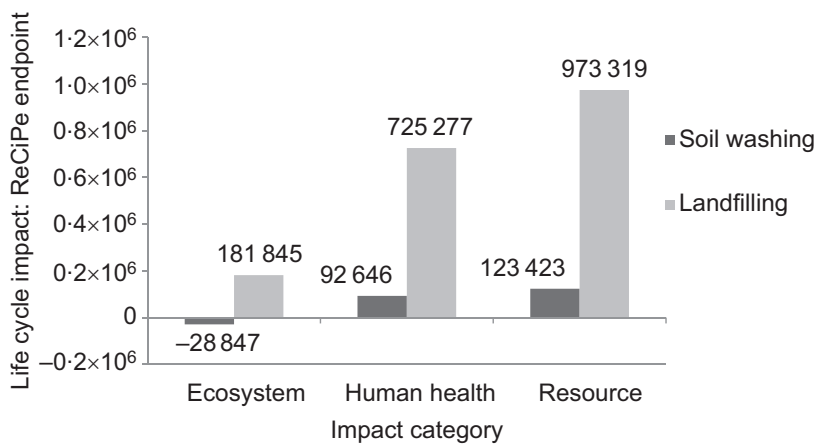

Figure 1. Life cycle impact estimated by ReCiPe endpoint hierarchist method. Soil washing considers impacts from excavation and soil washing/disposal and landfilling considers impacts from excavation and soil disposal

the ecological system and human health, and it also saved resource input. The results from the present study are consistent with an existing study, which found that soil washing resulted in a lower carbon footprint than excavation and disposal at the 2014 Commonwealth Games athletes' village (Sampson et al., 2013). The present study suggests that soil washing produces higher sustainability gains over landfilling. This is probably because the landfills used in the two studies were different and also because the soil recovered from the London Olympic Park site was used at the site, which avoided the import of that same amount of clean fill.

On the other hand, it should be noted that soil washing does not completely remove all contaminants in soil. The contaminant residual in soil entails some uncertainty in the long run, especially when site use changes. It is unlikely that such site use change is accounted for in LCA and the long-term risk of the contaminant residual is difficult to assess. It is important to implement appropriate institutional control measures to ensure such risk is minimised. At the Olympic Park, where residual contaminants exist above certain levels, restrictions were enforced such as ground should not be used for private gardening or the production of edible crops, and the final surface level must not be reduced without assessment of materials below enabling works sub-formation level. From a technical perspective, technology development towards higher removal efficiency in soil washing could be important in order to promote the use of soil washing, thus eliminating the need for such institutional control measures. Another lesson learned about soil washing at the Olympic Park was that washed soil may not always be suitable for recycling as surficial backfill. An invasive species, Japanese knotweed, started to grow in some of those areas. One likely reason was that some contaminated sediment that was washed and reused may have contained Japanese knotweed seeds. Even though this could 
Engineering Sustainability

Volume 168 Issue ES2
Sustainable site clean-up from

megaprojects: lessons from

London 2012

Hou, Al-Tabbaa and Hellings not be fully confirmed, it is an important lesson learned for future implementation of the soil washing technology. It is desirable to backfill washed soil and sediment to a deeper depth to avoid such issues.

\subsection{Social and economic sustainability considerations}

Several overarching sustainability strategies (see Section 4.3) involved social and economic sustainability: supporting communities, access, employment and business, health and wellbeing, and inclusion. Some of these strategies have direct or indirect implications for remediation of the contaminated site. In response, the planning and implementation of remediation activities at the site incorporated a number of social and economic sustainability considerations.

First of all, during the remediation work, cultural resources were protected. It is worth mentioning that, while this is standard practice in the UK, it is not in many other parts of the world. The authors consider such sustainable practices should be incorporated into future megaprojects, especially those organised in developing countries. In this project, the Museum of London Archaeology Service (MoLAS) produced a sitewide archaeological investigation strategy as part of the planning process, including maps containing planned trenches to determine archaeology. An archaeological and built heritage investigation, excavation and recording programme was conducted before construction work began in each construction zone. Where archaeological remains were found during the works, work was halted immediately and English Heritage was notified within $24 \mathrm{~h}$. During site preparation and remediation work, approximately 140 archaeology pits were excavated, uncovering over 10000 objects, including a nineteenth century boat, an eighteenth century roadway, Iron Age skeletons and a Bronze Age hut.

Second, the remediation work encouraged stakeholder engagement. Sustainability strategies were developed based on extensive consultation with key stakeholders, including various levels of government, the private sector, local communities and NGOs. One interviewee indicated that approximately 50-60 stakeholders were involved, including a large number of government agencies such as the five local authorities. Remediation planning was influenced by such stakeholder engagement activities. For instance, the extensive use of soil washing was partly attributed to stakeholder pressure (Maiden and Gray, 2013). During remediation, the following measures were taken to involve local communities and mitigate public concerns.

Communications with neighbouring residents were numerous.

- A 24 h hotline was made available to local residents.
- Site trips were organised for local residents to see the site clean-up work.

- Extensive nuisance mitigation measures (e.g. noise reduction and dust suppression) were taken.

- Residents' concerns were addressed immediately. For instance, some residents complained about bright night lighting and this was adjusted right away to avoid disturbance.

The findings from this study concur with previous findings, which suggest that direct stakeholder influence has limited effect on remediation decision-making, but institutionalised stakeholder influence does play an important role (Hou et al., 2014d).

Third - and probably the most important sustainability gain from remediation work in the London Olympic project - is the physical transformation of east London. The Olympic Park was developed on a largely derelict, polluted and inaccessible site, with a comprehensive programme of land acquisition, remediation and development. According to the ongoing legacy transformation project (LLDC, 2013), the Olympic Park will become one of London's most dynamic urban districts, creating local opportunities and transformational changes, and promoting regeneration and convergence for east London. Post-Games land use will include six permanent sporting venues, $91000 \mathrm{~m}^{2}$ of commercial space, $200000 \mathrm{~m}^{2}$ of retail space and nearly 10000 new homes (DCMS, 2013). The remediation and redevelopment of the site has also brought significant social gain in employment. Site construction work created over 9700 jobs for host borough residents and the new Westfield Stratford City brought 10000 permanent jobs, 3000 of which went to unemployed local Newham residents (DCMS, 2013). It is difficult to determine how large a percentage of these jobs can be attributed to the fact that a brownfield rather than a greenfield site was used to construct the Olympic Park. However, it is reasonable to consider that if a greenfield site had been used, the use of 'local' employment would be reduced because a smaller local community would have existed. More importantly, the development of the brownfield site brought work to a large number of previously unemployed people in this deprived area.

\subsection{Challenges encountered and lessons learned}

One of the biggest challenges associated with a megaproject is probably the mobilisation of site occupants. Many people lived and worked at the proposed London Olympic Park site prior to project initiation in 2007 and, according to one interviewee, nearly 5000 people moved from the site to government-built accommodation in one month. The challenge was not only logistical, but also emotional, as noted by a senior figure in the project team who said 
Engineering Sustainability

Volume 168 Issue ES2
Sustainable site clean-up from

megaprojects: lessons from

London 2012

Hou, Al-Tabbaa and Hellings
People had been there for a long time; some businesses had been there for centuries. It was very emotional to lose their properties. It was a social problem.

The lesson learned during this mobilisation phase was that good preparation (e.g. replacement accommodation and logistics) and truly caring for the occupants can make the process much easier.

Another challenge associated with the studied project was the tight schedule. The remediation work at the Olympic Park involved 246 ha of land that had been used for industrial activities for over 200 years. Typically, a remediation project of this magnitude would take 5 to 15 years to complete, but remediation at this site was completed in less than 3 years. Several factors may explain the expedited pace of these remediation operations.

- There was a solid deadline for Olympic delivery that was impossible to move. This affected the psychology of project team members and encouraged cooperation.

- Monthly meetings of all key stakeholders (i.e. regulators, consultants and contractors) were held, enabling all parties to know what was happening and ensuring close cooperation and smooth progress.

Working for the Olympics project was inspiring and this enhanced team members' engagement and their attitude.

- Regulators and consultants shared the same office, which made communication and the conquest of regulatory barriers easier.

A co-benefit of the tight schedule was financial as it is well known that construction project delay can result in huge extra costs (Nunnally, 2004). Megaprojects can thus present a great opportunity to redevelop brownfield sites, partly because brownfield remediation during such huge events can be more efficient due to the tight schedule and the pressure on all parties, including regulators. Moreover, brownfield remediation on such a large scale can reduce marginal cost. For instance, at the London Olympic Park, the unit cost of soil washing every $1 \mathrm{t}$ of contaminated soil was low because of the large-scale operation.

The use of suitable-for-use remediation design also created a challenge for future development due to the remaining contaminants at the site. A series of restrictions had to be placed on future work in order to protect human health and the environment. For instance, in the human health validation report for construction zone 4 (ODA, 2008), a series of restrictions on follow-on work was suggested, including the following.

- Any work that involves excavation through the marker layer would need to follow the permit to proceed protocol.
- Infrastructure and buildings need to be designed to be resistant to expected ground chemical conditions.

- Land use is to be restricted to commercial use and the site shall not be used for growing edible crops or private gardens.

Water infiltration on site shall be limited.

- Any change to currently defined legacy use would necessitate re-evaluation and may require further site investigation, assessment and remediation.

- Arisings from excavation below the marker layer shall be treated as contaminated unless proved otherwise; appropriate risk assessment is needed for such intrusive work.

It is also a challenge to take into account fully site investigation and remediation considerations during the master plan phase. By undertaking such efforts, the extent of land requiring intensive investigation and remediation can be reduced, with the least sensitive land uses (e.g. commercial buildings with hard landscape) placed in the most contaminated area and the most sensitive land uses (e.g. houses with gardens or nurseries) placed in the least contaminated area. However, because site investigation results tend to be limited during the master planning phase it is difficult to address fully the site contamination and remediation issue during this phase. Several lessons were identified in the present study regarding the use of a suitable-for-use strategy.

Firstly, the project had to use a complicated hybrid risk assessment method to meet UK regulatory requirements as well as addressing all risk exposure pathways, because the UK-specific contaminated land exposure assessment (CLEA) model does not address risk to groundwater. This is a lesson learned to policymakers because soil and groundwater are almost always interlinked and regulators need to combine rather than separate them. Secondly, the use of a suitable-for-use strategy can leave a burden to future generations. Actually, due to a change in planning, some post-Olympics construction had already restarted new remediation work. Nevertheless, the practice at the London Olympic Park is still an improvement over the 2000 Sydney Olympic Park remediation, where much more significant contaminant residual was left behind due to the extensive use of capping. In future megaprojects, project planners must give sufficient time and resources for the remediation phase in order to minimise the contaminant residual left behind.

Groundwater treatment at the Olympic Park site faced a number of technical challenges: treatment facilities were located around one of the largest and busiest construction sites in Europe, and it was also difficult to predict when the endpoint water quality standards might be met. In addressing a plume extending through several construction zones (ODA, 2010), it was determined that arsenic concentration would decrease very slowly and monitoring data collected over 1 year may not demonstrate whether the concentration was stable or 
Engineering Sustainability

Volume 168 Issue ES2
Sustainable site clean-up from

megaprojects: lessons from

London 2012

Hou, Al-Tabbaa and Hellings declining. Consequently, the site-specific remediation statement decided that demonstration of a stable condition could be supported by calculations estimating the rate at which concentrations in the plume area would decline over time. A lesson learned during groundwater treatment was that, because the groundwater table was shallow at the site and due to the influence of adjacent rivers, groundwater flow directions could change over different seasons. Consequently, the remedial design had to be adjusted during the course of remediation. Future remediation at megaprojects should thus be particularly careful about such potential changes because there is very limited time to allow for a change of design and implementation. While in situ remediation technologies were extensively used to clean up contaminated groundwater at the site, they were not as widely used in cleaning up contaminated soil at the site. The use of in situ soil remediation technologies can be challenging in megaprojects because such projects tend to have a tight schedule, but in situ remediation technologies tend to be more time consuming and there are also more technical uncertainties.

While the choice of sustainable remediation technologies (e.g. soil washing) provided much sustainability gains as illustrated in Section 4.6, it does not necessarily mean that soil washing is a more sustainable approach under all conditions. From a retrospective perspective, quantitative sustainability assessments (e.g. LCA) could have provided added value in the realisation of even more sustainability potentials (e.g. optimising the combination of various remediation technologies under various sitespecific characteristics). However, the project team did not conduct any quantitative sustainability assessment and finding out why this choice was made is unlikely. Nevertheless, an interviewee indicated that, during remediation implementation, a review of energy usage and effectiveness was conducted and the conclusion was that remediation efficiency was more important.

\section{Conclusion}

Sustainability has become a new imperative in contaminated land remediation and brownfield redevelopment. Incorporating sustainability into megaprojects is a challenge due to their complexity and time constraints. Remediation work at the 2012 London Olympic Park site has successfully demonstrated how sustainable construction practices can be incorporated into brownfield remediation and redevelopment projects. In the planning phase, a series of sustainability strategies was developed, suitable-for-use remediation design was utilised and remediation technologies were ranked according to their sustainability potential. During the implementation phase, the project had extensive stakeholder engagement activities, effectively protected cultural resources and greatly reduced life cycle environmental impact by using soil washing technology. There are also challenges and lessons learned from the London Olympic Park experience. The mobilisation of site occupants and a tight schedule were both big challenges. The use of suitable-for-use remediation design, while saving many remediation requirements, also meant that some residual contaminants were left and these pose a challenge for future development of the site. It should be noted that the London Olympic Park site was used as an exploratory case study. The ideas and hypotheses generated in this study should be subjected to rigorous empirical testing at a later stage in larger scale studies.

\section{Acknowledgement}

Funding for this research was provided by the Cambridge International Scholarships Scheme (\#10191612), which is gratefully acknowledged.

\section{REFERENCES}

Al-Tabbaa A, Harbottle M and Evans C (2007) Robust sustainable technical solutions. In Sustainable Brownfield Regeneration (Dixon T et al. (eds)). Blackwell Publishing, Oxford, UK.

Altshuler AA and Luberoff D (2003) Mega-Projects: The Changing Politics of Urban Public Investment, Brookings Institution Press, Washington, DC, USA.

Beyer S (2006) The green Olympic movement: Beijing 2008. Chinese Journal of International Law 5(2): 423-440.

Clarinet (Contaminated Land Rehabilitation Network for Environmental Technologies) (2002a) An Analysis of National and EU RTD Programmes Related to Sustainable Land and Groundwater Management. Clarinet, Vienna, Austria (succeeded by Common Forum on Contaminated Land in the European Union).

Clarinet (2002b) Sustainable Management of Contaminated Land: An Overview. Clarinet, Vienna, Austria (succeeded by Common Forum on Contaminated Land in the European Union).

CSL (Commission for a Sustainable London 2012) (2010) No Time to Waste: A Review of Waste and Resource Management across the London 2012 Programme. CSL, London, UK.

DCMS (Department for Culture, Media and Sport) (2013) Report 5: Post-Games Evaluation, Meta-Evaluation of the Impacts and Legacy of the London 2012 Olympic Games and Paralympic Games, Summary Report. DCMS, London, UK. Defra and EA (Department for Environment, Food and Rural Affairs and Environment Agency) (2004) CLR 11: Model Procedures for the Management of Land Contamination. Environment Agency, Bristol, UK.

Ellis DE and Hadley PW (2009) Sustainable remediation white paper - integrating sustainable principles, practices, and metrics into remediation projects. Remediation Journal 19(3): 5-114.

Fainstein SS (2008) Mega-projects in New York, London and Amsterdam. International Journal of Urban and Regional Research 32(4): 768-785.

Frischknecht $\mathrm{R}$, Jungbluth $\mathrm{N}$, Althaus $\mathrm{H}$ et al. (2007) Implementation of Life Cycle Impact Assessment Methods: Data v2.0. Ecoinvent Report No. 3. Swiss Centre for Life Cycle Inventories. See http://www.ecoinvent.org (accessed 25/11/2014) 
Engineering Sustainability

Volume 168 Issue ES2
Sustainable site clean-up from

megaprojects: lessons from

London 2012

Hou, Al-Tabbaa and Hellings
Goedkoop M and Spriensma R (2013) ReCiPe 2008: A Life Cycle Impact Assessment Method which Comprises Harmonised Category Indicators at the Midpoint and the Endpoint Level; First Edition Report I: Characterisation. See http://www.lcia-recipe.net (accessed 25/11/2014).

Hellings J, Lass M, Apted J and Mead I (2011) Delivering London 2012: geotechnical enabling works. Proceedings of the Institution of Civil Engineers - Civil Engineering 164(11): 5-10.

Hou D and Al-Tabbaa A (2014) Sustainability: A new imperative in contaminated land remediation. Environmental Science and Policy 39(5): 25-34.

Hou D, Al-Tabbaa A and Guthrie P (2014a) The adoption of sustainable remediation behaviour in the US and UK: A cross country comparison and determinant analysis. Science of the Total Environment 490(2014): 905-913.

Hou D, Al-Tabbaa A and Luo J (2014b) Assessing effects of site characteristics on remediation secondary life cycle impact with a generalized framework. Journal of Environmental Planning and Management 57(7): 1083-1100.

Hou D, Al-Tabbaa A, Guthrie P et al. (2014c) Using a hybrid LCA method to evaluate the sustainability of sediment remediation at the London Olympic Park. Journal of Cleaner Production 83(2014): 87-95.

Hou D, Al-Tabbaa A, Chen H et al. (2014d) Factor analysis and structural equation modeling of sustainable behaviour in contaminated land remediation. Journal of Cleaner Production 84(2014): 439-449.

ISO (International Organization for Standardization) (2006) ISO 14040: Environmental management - Life cycle assessment - Principles and framework. Environmental Management 3(1): 28. See http://www.iso.org/iso/catalogue_detail? csnumber $=37456$ (accessed 25/11/2014).

Lemming G, Hauschild MZ and Bjerg PL (2010) Life cycle assessment of soil and groundwater remediation technologies: literature review. International Journal of Life Cycle Assessment 15(1): 115-127.

Lenskyj HJ (1998) Sport and corporate environmentalism: The case of the Sydney 2000 Olympics. International Review for the Sociology of Sport 33(4): 341-354.

LLDC (London Legacy Development Corporation) (2013) Three Year Business Plan 2013/14-2015/16. LLDC, London, UK.

Maiden T and Gray D (2013) Commission for a Sustainable London 2012: Independent Evaluation. CAG Consultants, London, UK.

Morais SA and Delerue-Matos C (2010) A perspective on LCA application in site remediation services: critical review of challenges. Journal of Hazardous Materials 175(1-3): 1222. See http://www.ncbi.nlm.nih.gov/pubmed/19910112 (Accessed 25/09/2011).

Nicole (Network for Industrially Contaminated Land in Europe) (2002) Need for Sustainable Land Management: Role of a Risk Assessment Based Approach. Nicole, Utrecht, The Netherlands.
Nicole (2005) The Impact of EU Directives on the Management of Contaminated Land. Nicole, Utrecht, The Netherlands.

Nicole (2008) Report of the NicolelSAGTA Workshop:

Sustainable Remediation. Nicole, Utrecht, the Netherlands. Nunnally SW (2004) Construction Methods and Management. Pearson Prentice Hall, Upper Saddle River, NJ, USA. ODA (Olympic Delivery Authority) (2007a) Sustainable Development Strategy. ODA, London, UK.

ODA (2007b) Global Remediation Strategy: Olympic, Paralympic \& Legacy Transformation Planning Applications, Site Preparation Planning Application. ODA, London, UK. ODA (2007c) Environmental Statement Annexure, Transport Assessment, Olympic, Paralympic \& Legacy Transformation Planning Applications. ODA, London, UK.

ODA (2007d) Remediation Design Statement. ODA, London, UK. ODA (2008) CZ4 Ground Contamination Remediation Human Health Validation Report. ODA, London, UK.

ODA (2010) Addendum to the CZ2a, CZ2b, CZ3a [Banner Chemicals], CZ3b [Pumping Station], CZ8a, CZ8b and CZ8c Remediation Method Statements - Southern Groundwater Plume. ODA, London, UK.

Orueta FD and Fainstein SS (2008) The new mega-projects: genesis and impacts. International Journal of Urban and Regional Research 32(4): 759-767.

Sampson J, Biesta M, Crapper M, Hall I and Shepherd A (2013) Carbon dioxide accounting: 2014 Commonwealth Games Athletes' Village. Proceedings of the Institution of Civil Engineers - Engineering Sustainability 166(3): 150-160.

Short K (1993) Environmental Guidelines for the Summer Olympic Games. Sydney Olympics 2000 Bid Limited, Sydney, Australia. Surf-UK (Sustainable Remediation Forum in the UK) (2010) $A$ Framework for Assessing the Sustainability of Soil and Groundwater Remediation. Contaminated Land: Applications in Real Environments. Surf-UK, London, UK. Van Zelm R, Huijbregts MAJ and van de Meent D (2009) USESLCA 2.0 - a global nested multi-media fate, exposure, and effects model. International Journal of Life Cycle Assessment 14(3): 282-284.

\section{WHAT DO YOU THINK?}

To discuss this paper, please email up to 500 words to the editor at journals@ice.org.uk. Your contribution will be forwarded to the author(s) for a reply and, if considered appropriate by the editorial panel, will be published as discussion in a future issue of the journal.

Proceedings journals rely entirely on contributions sent in by civil engineering professionals, academics and students. Papers should be 2000-5000 words long (briefing papers should be 1000-2000 words long), with adequate illustrations and references. You can submit your paper online via www.icevirtuallibrary.com/content/journals, where you will also find detailed author guidelines. 